Article

\title{
Thermodynamic Analysis and Experimental Study of Selective Dehydrogenation of 1,2-cyclohexanediol over $\mathrm{Cu}_{2+1} \mathrm{O} / \mathrm{MgO}$ Catalysts
}

\author{
Haiou Wang ${ }^{1}$, Qiusheng Yang ${ }^{1,2, *}$, Yucong Song ${ }^{1}$ and Yanji Wang ${ }^{1,2, *}$ \\ 1 School of Chemical Engineering, Hebei University of Technology, Tianjin 300130, China; \\ wanghaiou@hebut.edu.cn (H.W.); yucong0508@163.com (Y.S.) \\ 2 Hebei Province Technology Institute of Green Chemical Industry, Hebei University of Technology, \\ Tianjin 300130, China \\ * Correspondence: yqiusheng@hebut.edu.cn (Q.Y.); yjwang@hebut.edu.cn (Y.W.)
}

Received: 21 January 2019; Accepted: 9 February 2019; Published: 10 February 2019

\begin{abstract}
The dehydrogenation of 1,2-cyclohexanediol (CHD) helps in the effective utilization of not only fossil derivatives but also vicinal diols and polyols from sustainable biomass-derived resources. A thermodynamic analysis of CHD dehydrogenation was computed with density functional theory (DFT) calculation using Gaussian 09. The result indicates that CHD can be converted to 2-hydroxy cyclohexanone (HCO), 2-hydroxy-2-cyclohexen-1-one (HCEO) and pyrocatechol depending on the degree of dehydrogenation. HCO and HCEO are the stable products of the primary and secondary dehydrogenation. Experimentally, $\mathrm{Cu} / \mathrm{MgO}$ catalysts were prepared using glucose as a reductant, and were characterized by SEM, TEM, XRD, XPS, TPR, BET and ICP. Furthermore, their catalytic performance regarding the oxygen-free dehydrogenation of $\mathrm{CHD}$ was investigated. The results indicate that the primary active crystalline phase of $\mathrm{Cu} / \mathrm{MgO}$ was $\mathrm{Cu}_{2+1} \mathrm{O}$, and that the dehydrogenation products were mainly $\mathrm{HCO}$ and $\mathrm{HCEO}$, in accordance with thermodynamic predictions. Upon optimizing the reaction conditions, the total selectivity of HCO and HCEO exceeded $90 \%$ and the conversion of CHD was approximately $95 \%$.
\end{abstract}

Keywords: 1,2-cyclohexanediol; $\mathrm{Cu}_{2+1} \mathrm{O} / \mathrm{MgO}$; dehydrogenation; 2-hydroxy cyclohexanone; 2-hydroxy-2-cyclohexen-1-one

\section{Introduction}

In recent years, the process of producing cyclohexene via the selective hydrogenation of benzene has greatly matured [1-4], having laid a critical foundation for the efficient use of coal. It has been reported that a variety of essential chemical products can be developed from the oxidation of cyclohexene, such as 1,2-cyclohexanediol (CHD), cyclohexane oxide, adipic acid [5-7] etc. More specifically, CHD can be refined into pyrocatechol [8,9], adipic acid [10,11], cyclohexanone [12], and heterocyclic compounds [13-15], etc. Currently, the prevalent studies on the dehydrogenation of CHD rely on stoichiometric oxidants, such as $\mathrm{NaBrO}_{3} / \mathrm{NaHSO}_{3}[16], \mathrm{O}_{3}, \mathrm{O}_{2}[17,18], \mathrm{KMnO}_{4}$, $\mathrm{K}_{2} \mathrm{CrO}_{4}$, tert-butyl hydroperoxide [19] and $\mathrm{H}_{2} \mathrm{O}_{2}$ [20], etc. The primary product produced from the dehydrogenation of $\mathrm{CHD}$ is 2-hydroxy cyclohexanone (HCO), but CHD can be further dehydrogenated to form other products (e.g., 1,2-cyclohexanedione and adipic acid [16]) either under excess oxidant concentration, a prolonged reaction time or a high reaction temperature. For example, Vermaet et al [20] used PEG $\cdot \mathrm{KBr}_{3}$ to catalyze the dehydrogenation of $\mathrm{CHD}$, by which the $\mathrm{CHD}$ in $\mathrm{H}_{2} \mathrm{O}_{2}$ can be oxidized to $\mathrm{HCO}$ or cyclohexanedione by tuning the reaction temperature and the ratio of reactants. In acetonitrile, $\mathrm{CHD}$ can be converted into cyclohexanedione, $\mathrm{HCO}$ and adipic acid catalyzed by $\mathrm{Q}_{3} \mathrm{H}_{2}\left[\mathrm{IMo}_{6} \mathrm{O}_{24}\right]$ $\left(\mathrm{Q}=(\mathrm{n}-\mathrm{Bu})_{4} \mathrm{~N}^{+}\right)$at $80^{\circ} \mathrm{C}$ [21]. Furthermore, in the presence of excessive oxidants, this not only resulted 
in a variety of byproducts, but also recycled excessive oxidants difficultly. Lastly, an excessive number of oxidants increased the likelihood of an explosion via a massive exothermic process.

A possible solution for mitigating this setback was to undergo oxygen-free dehydrogenation. Research into the oxygen-free dehydrogenation of CHD has mainly focused on nickel-based [8] and palladium-based [9] catalysts, while the main product, pyrocatechol, was formed by the deep dehydrogenation of CHD. Few papers have reported the oxygen-free dehydrogenation of CHD to HCO. Sato et al. studied the synthesis of HCO from CHD by oxygen-free dehydrogenation

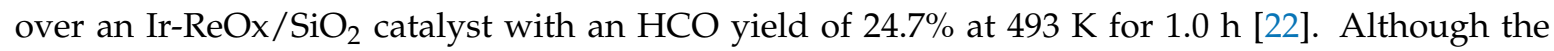
$\mathrm{Cu}$-based catalyst was also an important catalyst, which has been widely used in the dehydrogenation of alcohols [23], it has not been reported in the oxygen-free dehydrogenation of CHD to HCO or 2-hydroxy-2-cyclohexen-1-one (HCEO). The main active components of $\mathrm{Cu}$-based catalysts are $\mathrm{Cu}^{0}$ and $\mathrm{Cu}^{+}$, the latter possessing better activity and selectivity. Especially at higher temperatures, $\mathrm{Cu}^{0}$ will increase the yield of the phenol byproduct [24-27]. In addition, both dehydrogenated intermediates of $\mathrm{CHD}, \mathrm{CHO}$ and $\mathrm{CHEO}$ are not only used as raw material for adipic acid synthesis but are also common building blocks for asymmetric and heteropoly cyclic compounds [28-32]. Thus, it is crucial to investigate the controlled dehydrogenation of CHD to HCO and HCEO over Cu-based catalysts. Furthermore, the dehydrogenation of $\mathrm{CHD}$ as a model compound can play an indispensable role for the effective utilization of environmentally-friendly and sustainable resources, since vicinal diols and polyols are common moieties in biomass-derived molecules.

In this work, the reaction thermodynamics of CHD oxygen-free dehydrogenation was computed by Gaussian 2009 at the B3LYP/6-31G+(d, p) level for the preliminary screening of the stability of the possible products. Then, the highly reactive $\mathrm{Cu} / \mathrm{MgO}$ catalysts were prepared by the impregnation and precipitation method, and were characterized by SEM, TEM, XRD, XPS, TPR, BET and ICP techniques. Lastly, their catalytic performance for dehydrogenating CHD was evaluated on a fixed-bed reactor.

\section{Materials and Methods}

\subsection{Preparation of $\mathrm{Cu} / \mathrm{MgO}$ Catalyst}

$\mathrm{Cu} / \mathrm{MgO}$ was prepared by two different methods. (1) Precipitation method: One hundred milliters of $4.0 \mathrm{M} \mathrm{NaOH}$ solution was quickly added into a $500 \mathrm{~mL}$ three-necked flask containing $100 \mathrm{~mL}$ of $2.0 \mathrm{M} \mathrm{Mg}\left(\mathrm{NO}_{3}\right)_{2}$ solution under vigorous stirring at $80^{\circ} \mathrm{C}$. After stirring for $30 \mathrm{~min}, 1.0 \mathrm{M}$ $\mathrm{Cu}\left(\mathrm{NO}_{3}\right)_{2}$ solution and $1.0 \mathrm{M}$ glucose solution were added dropwise into the flask. Subsequently, the $\mathrm{pH}$ value was adjusted to about 10 11 by the slow addition of a $1.0 \mathrm{M}$ aqueous solution of $\mathrm{NaOH}$, followed by a $1.0 \mathrm{~h}$ continuous reduction reaction. Then, the mixture was filtered and the precipitate was washed with ethanol and water three times each. Finally, the precipitate was dried at $110^{\circ} \mathrm{C}$ for $12.0 \mathrm{~h}$, and subsequently calcined for $3 \mathrm{~h}$ to form $x \mathrm{Cu} / \mathrm{MgO}-\mathrm{C}-\mathrm{T}$ catalyst (where $x$ is the mass ratio of $\mathrm{Cu}$ to $\mathrm{MgO}, \mathrm{C}$ represents the precipitation method, $\mathrm{T}$ is the calcination temperature). (2) Impregnation method: The precipitation of $\mathrm{Mg}(\mathrm{OH})_{2}$ prepared by the above method was first calcined at $400{ }^{\circ} \mathrm{C}$ to form an $\mathrm{MgO}$ support. The $\mathrm{MgO}$ support was then impregnated into the $1.0 \mathrm{M} \mathrm{Cu}\left(\mathrm{NO}_{3}\right)_{2}$ solution for $24 \mathrm{~h}$. Next, the samples were treated similarly to that of the precipitation method; i.e., reduced by $\mathrm{NaOH}$ and glucose solution, filtrated, washed, dried and calcined for $3.0 \mathrm{~h}$ to form $x \mathrm{Cu} / \mathrm{MgO}-\mathrm{IM}-\mathrm{T}$ (where IM represents the impregnation method).

All the reagents above were analytical grade and purchased from Bodi Chemical Reagent Factory Co. Ltd., Tianjin, China.

\subsection{Catalyst Characterization}

X-ray diffractometry (XRD): The crystalline phases of samples were detected by a D/MAX2RB $\mathrm{X}$-ray diffractometer (Rigaku International Corporation, Japan) with monochromatic $\mathrm{Cu} \mathrm{K} \alpha$ radiation. The scan range spanned from $5^{\circ}$ to $90^{\circ}$ at a rate of $4^{\circ} / \mathrm{min}$. 
Scanning electron microscopy (SEM): SEM was performed with an EGA TS-5130SB scanning electron microscope (TESCAN, Czech). The micrographs were obtained at an accelerating potential of $15 \mathrm{kV}$ under low vacuum.

High resolution transmission electronic microscopy (HRTEM): The size and distribution of samples were conducted by using a Tecnai G2 F20 high resolution transmission electronic microscope (FEI, Netherlands) with a point resolution of $0.248 \mathrm{~nm}$ and a linear resolution of $0.248 \mathrm{~nm}$. The maximum enlargement factor of this equipment was 1.05 million.

Specific surface area analysis.: The specific surface area of samples was obtained from an $\mathrm{N}_{2}$ adsorption-desorption isotherm at $77 \mathrm{~K}$ with a Micromeritics ASAP 2020 Surface Area and Porosity Analyzer (Micromeritics Instrument Corp., USA), after degassing at $200{ }^{\circ} \mathrm{C}$ and $10 \mu \mathrm{mHg}$ for $4 \mathrm{~h}$. Multipoint BET analysis method was used to calculate the specific surface area.

Temperature-programmed reduction $\left(\mathrm{H}_{2}-\mathrm{TPR}\right)$.: TPR tests were carried out on Micromeritics Auto Chem II-2920 Chemisorption Analyzer (Micromeritics, USA). The samples were pretreated in a flow of $\operatorname{Ar}\left(50 \mathrm{~mL} / \mathrm{min}\right.$ ) at room temperature for $1.0 \mathrm{~h}$. Subsequently, the gas flow was switched to $\mathrm{H}_{2}$ (10 vol\% in Ar, $50 \mathrm{~mL} / \mathrm{min}$ ) and the sample was heated to $900{ }^{\circ} \mathrm{C}$ at a ramp rate of $10{ }^{\circ} \mathrm{C} / \mathrm{min}$. The $\mathrm{H}_{2}$ consumption was monitored by a thermal conductivity detector (TCD).

X-ray photoelectron spectroscopy (XPS) and Auger electron spectroscopy (AES): XPS and AES of samples were performed with an HI-1600 X-ray photoelectron microscope (PE, USA) with a monochromatic $\mathrm{Mg} \mathrm{K} \alpha$ radiation $(1253.6 \mathrm{eV})$ as the $\mathrm{X}$-ray excitation source. The energies of the full spectrum and the narrow spectrum were $187.8 \mathrm{eV}$ and $23 \mathrm{eV}$, respectively. The binding energy of C1s $(284.6 \mathrm{eV})$ was used as a calibration standard.

Inductively coupled plasma-atomic emission spectrometry (ICP-AES): The elemental composition of the catalysts was determined by ICP-AES on an Optima $7300 \mathrm{~V}$ spectrometer (PE, USA).

\subsection{Evaluation of Catalytic Activity}

The catalytic performance of catalysts for the dehydrogenation of CHD was evaluated on a fixed-bed reactor composed of a stainless-steel tube with an inner diameter of $5 \mathrm{~mm}$. The operational process was as follows: $1.0 \mathrm{~g}$ of catalyst and an equal volume of quartz sand were mixed and packed in the thermostatic zone of the reactor. Then, the feed of CHD solution ( $25 \mathrm{mg} \mathrm{CHD} / \mathrm{mL}$ tetrahydrofuran) was pumped into the reactor after the catalyst bed was heated to the reaction temperature, and the system pressure was maintained at $0.5 \mathrm{MPa}$ with $\mathrm{N}_{2}$. During the reaction process, sampling was regularly withdrawn for quantitative analysis.

The reaction products were quantitatively analyzed on a SP3400 gas chromatograph (Beijing Beifen Ruili Analytical Instrument co. Ltd, China) with a PEG-20M capillary column. The analysis conditions were as follows: $\mathrm{N}_{2}$ carrier gas was flowed at a rate of $30 \mathrm{~mL} / \mathrm{min}$, a FID (Flame Ionization Detector) temperature of $220^{\circ} \mathrm{C}$, and an injection port temperature of $220^{\circ} \mathrm{C}$. The column temperature was programmed as follows: the initial oven temperature was set at $80^{\circ} \mathrm{C}$ and then increased at a rate of $10^{\circ} \mathrm{C} \cdot \mathrm{min}^{-1}$ to $240{ }^{\circ} \mathrm{C}$ and then held for $3 \mathrm{~min}$. Lastly, the conversion of $\mathrm{CHD}$ and the yield of products were calculated by using the area normalization method.

\subsection{Calculation of Thermodynamics}

Gaussian 09 software was used to thermodynamically evaluate the dehydrogenation reaction at the B3LYP/DFT level [33]. All atoms were determined by the 6-31G $+(\mathrm{d}, \mathrm{p})$ basis set. The solvent effect was calculated by using the polarized continuum model (PCM) [34]. The geometry optimization and frequency were calculated to avoid the emergence of an imaginary frequency in the same methods, which referred to each species. If not noted otherwise, the thermal enthalpies $(\Delta \mathrm{H})$ and free energies $(\Delta G)$ of the reaction reported in this article were estimated at the relative energies, which refer to those with zero-point energy (ZPE) correction. 


\section{Results and Discussion}

\subsection{Thermodynamic Analysis}

\subsubsection{Stability Analysis of Primary Dehydrogenation Products}

Density functional theory (DFT) calculations were used to predict the possible isomers of the dehydrogenated products. Meanwhile, the thermal equilibrium of dehydrogenation was also calculated. The possible dehydrogenated products and corresponding calculations are summarized in Table 1.

Table 1. $\Delta \mathrm{G}$ of different isomers of dehydrogenation products.

\begin{tabular}{|c|c|c|c|c|c|c|}
\hline \multirow[b]{2}{*}{$\mathrm{T}\left({ }^{\circ} \mathrm{C}\right)$} & \multicolumn{3}{|c|}{$\begin{array}{l}\text { Primary Dehydrogenation Product } \\
\text { (kcal/mol) }\end{array}$} & \multicolumn{3}{|c|}{$\begin{array}{l}\text { Secondary Dehydrogenation Product } \\
(\mathrm{kcal} / \mathrm{mol})\end{array}$} \\
\hline & & & & & & \\
\hline $25^{\mathrm{a}}$ & 0.00 & 17.52 & 23.15 & 0.00 & 5.75 & 30.00 \\
\hline $100^{a}$ & 0.00 & 13.89 & 18.43 & 0.00 & 4.33 & 23.84 \\
\hline $220^{\mathrm{a}}$ & 0.00 & 10.35 & 18.26 & 0.00 & 3.91 & 23.56 \\
\hline $25^{\mathrm{b}}$ & 0.00 & 18.71 & 23.72 & 0.00 & 0.91 & 30.04 \\
\hline $25^{c}$ & 0.00 & 18.98 & 24.25 & 0.00 & 0.71 & 30.04 \\
\hline
\end{tabular}

${ }^{\mathrm{a}}$ Gas phase; ${ }^{\mathrm{b}}$ acetonitrile solvent; ${ }^{\mathrm{c}}$ water solvent.

The products of primary dehydrogenation generate three possible isomers, and their corresponding Gibbs free energies are compiled in Table 1. According to the Arrhenius formula, at $25{ }^{\circ} \mathrm{C}$ and under $1 \mathrm{~atm}$, the molar ratio of these three isomers is $10 \mathrm{E}(+10): 2.5 \mathrm{E}(+3): 8.8$, which indicates $\mathrm{HCO}$ would be the dominant structure, accounting for more than $99.9 \%$ of all products. The secondary dehydrogenation products also generate three possible isomers. Likewise, at $25^{\circ} \mathrm{C}$ and under $1 \mathrm{~atm}$, the ratio of these three isomers is $10 \mathrm{E}(+13): 3.1 \mathrm{E}(+11): 9.4$ according to the Arrhenius formula, which shows that HCEO accounted for over $99 \%$ of the formed products. Moreover, when the temperature of the gas phase of the system rises to at least $100{ }^{\circ} \mathrm{C}$, the cyclohexadione isomer occupies only about $1 \sim 4 \%$ of all structures. In short, these $o$-diketone structures are not very stable in the gas phase. In addition, in either an acetonitrile or water solvent, cyclohexadione occupies $32 \%$ and $29 \%$, respectively, of the total secondary products. Due to the conjugation nature of HCEO, the carbon-carbon single bond adjoined to the hydroxyl oxygen is not easily broken, whereas the carbon-carbon bond is easily severed owing to the two adjacent ketones, which rationalizes why the carbon-carbon bond of cyclohexadione can be easily oxidized.

\subsubsection{Thermodynamic Analysis of the Dehydrogenation Reaction in the Gas Phase}

CHD usually produces stable pyrocatechol through deep dehydrogenation. The reaction process is shown in Equation (1). The results of the thermodynamic calculation for the dehydrogenation of CHD are shown in Table 2. This indicates that the three-step dehydrogenation reactions of CHD are all endothermic reactions, in which the amount of heat absorbed from the largest to the smallest is in the order of the second step, then the first step, and then the third step. As the temperature increases, the reaction accelerates, the equilibrium shifts towards the right of the reaction, and the conversion rate increases. Actually, the second step of the dehydrogenation is the most critical step of the entire reaction. In fact, the temperature of the first step will occur spontaneously at about $114{ }^{\circ} \mathrm{C}$; however, the second step occurs only when the temperature exceeds $340{ }^{\circ} \mathrm{C}$, while the last step can occur at least $32{ }^{\circ} \mathrm{C}$. When the first two steps are combined, the temperature of the reaction can occur spontaneously at $227^{\circ} \mathrm{C}$; however, when all three steps are combined, the temperature of the reaction can occur 
at $160{ }^{\circ} \mathrm{C}$. Furthermore, at a temperature of $250{ }^{\circ} \mathrm{C}$, the equilibrium conversion rate of the first step reaction will be an impressive $98.3 \%$.

Table 2. The thermodynamic data of the stepwise dehydrogenation reaction in the gas phase.

\begin{tabular}{ccccccc}
\hline \multirow{2}{*}{$\mathbf{T}\left({ }^{\circ} \mathbf{C}\right)$} & \multicolumn{3}{c}{$\Delta \mathbf{H}(\mathbf{k c a l} / \mathbf{m o l})$} & \multicolumn{3}{c}{$\Delta \mathbf{G}(\mathbf{k c a l} / \mathbf{m o l})$} \\
\cline { 2 - 7 } & $\mathbf{( 1 )}$ & $\mathbf{( 2 )}$ & $\mathbf{( 3 )}$ & $\mathbf{( 1 )}$ & $\mathbf{( 2 )}$ & $\mathbf{( 3 )}$ \\
\hline 25 & 11.59 & 18.21 & 8.97 & 2.74 & 9.57 & 0.15 \\
50 & 11.70 & 18.34 & 9.13 & 2.00 & 8.84 & -0.60 \\
100 & 11.89 & 18.57 & 9.44 & 0.48 & 7.36 & -2.13 \\
150 & 12.05 & 18.78 & 9.72 & -1.06 & 5.84 & -3.70 \\
200 & 12.18 & 18.96 & 9.98 & -2.61 & 4.30 & -5.30 \\
$\mathbf{2 2 0}$ & $\mathbf{1 2 . 2 3}$ & $\mathbf{1 9 . 0 3}$ & $\mathbf{1 0 . 0 7}$ & -3.24 & 3.68 & -5.94 \\
250 & 12.30 & 19.12 & 10.20 & -4.18 & 2.74 & -6.92 \\
300 & 12.39 & 19.25 & 10.40 & -5.76 & 1.17 & -8.57 \\
\hline
\end{tabular}

Generally, hydrogen can maintain the oxidation performance of catalysts [35,36]. If the hydrogen amount in the system is up to 10 times that of stoichiometry, the equilibrium conversion rate of the first step will be restricted to $83.7 \%$ at $250{ }^{\circ} \mathrm{C}$. Additionally, if the hydrogen in the system is again lowered to 2 times, the conversion rate of the first step will again be limited to $90.4 \%$ at $220^{\circ} \mathrm{C}$. The conversion rate of the first step of the dehydrogenation will be at $96.6 \%$ at the same temperature under the oxygen-free dehydrogenation condition. Therefore, the hydrogen removed from the system will not affect the reaction obviously; on the contrary, it may also help to keep the catalyst active [8,12].

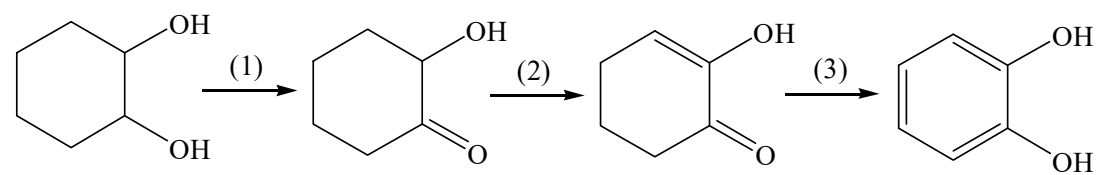

Additionally, the dehydration reaction is the primary side reaction during the dehydrogenation of $\mathrm{CHD}$ [12], which is followed by a ring-opening and fragmentation reaction at higher temperatures. At $220{ }^{\circ} \mathrm{C}$, the free energy of the dehydration step, producing cyclohexanone, is $-23.68 \mathrm{kcal} / \mathrm{mol}$, which is far lower than that of the entire dehydrogenation reaction. Therefore, the dehydration needs to be strictly inhibited by a better catalyst. On the other hand, alcoholysis usually involves free radical reactions at higher temperatures. Thus, the reaction temperature should be appropriately controlled in order to decrease pyrolysis products.

\subsection{Catalyst Characterization Results}

$\mathrm{Cu} / \mathrm{MgO}$ catalysts with different $\mathrm{Cu}$ loadings were prepared by the precipitation method and calcined at $250{ }^{\circ} \mathrm{C}$ and $350{ }^{\circ} \mathrm{C}$ in an $\mathrm{N}_{2}$ environment. Their XRD spectra are presented in Figure 1. Compared with the standard charts of JCPDS 76-0667, 45-0946 and 05-0667, $2 \theta$ angles of $18.6^{\circ}, 38.0^{\circ}$, $50.8^{\circ}$ and $58.7^{\circ}$ were matched with the $001,011,012$ and 110 crystal face diffraction peaks of $\mathrm{Mg}(\mathrm{OH})_{2}$, respectively. Furthermore, the $2 \theta$ angles of $42.9^{\circ}$ and $62.3^{\circ}$ were matched with the 200 and 220 crystal face diffraction peaks of $\mathrm{MgO}$, respectively. Lastly, the $2 \theta$ angles of $29.3^{\circ}, 36.5^{\circ}, 42.3^{\circ}, 61.3^{\circ}$ and $73.4^{\circ}$ corresponded to the 110,111, 200, 220 and 311 crystal face diffraction peaks of $\mathrm{Cu}_{2+1} \mathrm{O}$, respectively. These results indicate that $\mathrm{Mg}(\mathrm{OH})_{2}$ was decomposed into $\mathrm{MgO}$ as the temperature increased from $250{ }^{\circ} \mathrm{C}$ to $350{ }^{\circ} \mathrm{C}$. In addition, there was no evident crystalline phase of $\mathrm{Mg}(\mathrm{OH})_{2}$ in the samples calcined at $350{ }^{\circ} \mathrm{C}$, because $350{ }^{\circ} \mathrm{C}$ was the lowest temperature for the complete decomposition of $\mathrm{Mg}(\mathrm{OH})_{2}$ [37]. However, the crystalline phase of $\mathrm{Cu}_{2+1} \mathrm{O}$ could be detected after being calcined at 
temperature of at least $250{ }^{\circ} \mathrm{C}$. Under alkaline conditions $(\mathrm{pH}=10 \sim 12)$, glucose can reduce $\mathrm{Cu}^{2+}$ to $\mathrm{Cu}^{+}$due to its weak reducibility, as shown in Equation (2).

$$
\mathrm{Cu}^{2+}+\mathrm{C}_{5} \mathrm{H}_{11} \mathrm{O}_{5}-\mathrm{CHO}(\mathrm{aq}) \rightarrow \mathrm{Cu}_{2} \mathrm{O}(\mathrm{s})+\mathrm{C}_{5} \mathrm{H}_{11} \mathrm{O}_{5} \mathrm{COOH}(\mathrm{aq})
$$

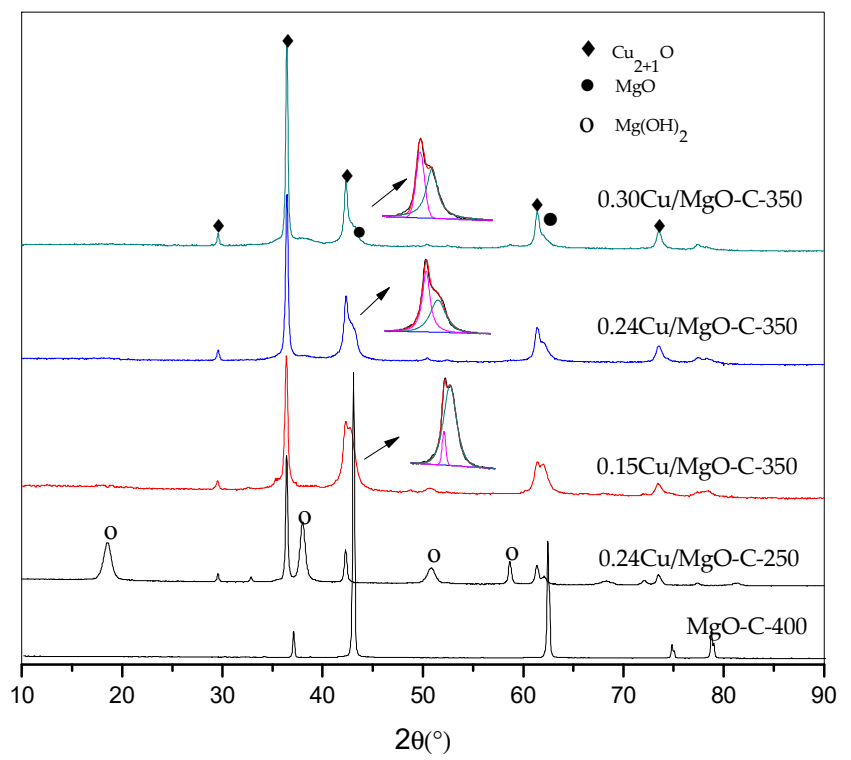

Figure 1. XRD patterns of $\mathrm{Cu} / \mathrm{MgO}$ catalysts with different $\mathrm{Cu}$ loadings.

Elemental $\mathrm{Cu}$ mainly existed in the form of crystalline phase of $\mathrm{Cu}_{2+1} \mathrm{O}$. Based on the (111) crystal face and Scherrer's equation, the crystallite size of the prepared $\mathrm{Cu}_{2+1} \mathrm{O}$ at various $\mathrm{Cu}$ concentrations was about $30 \mathrm{~nm}$. The SEM images of $0.24 \mathrm{Cu} / \mathrm{MgO}-\mathrm{C}-350$ and $0.30 \mathrm{Cu} / \mathrm{MgO}-\mathrm{C}-350$ are shown in Figure 2. It can be seen that the particle size of these catalysts was about $30 \mathrm{~nm}$, which was consistent with the XRD results.
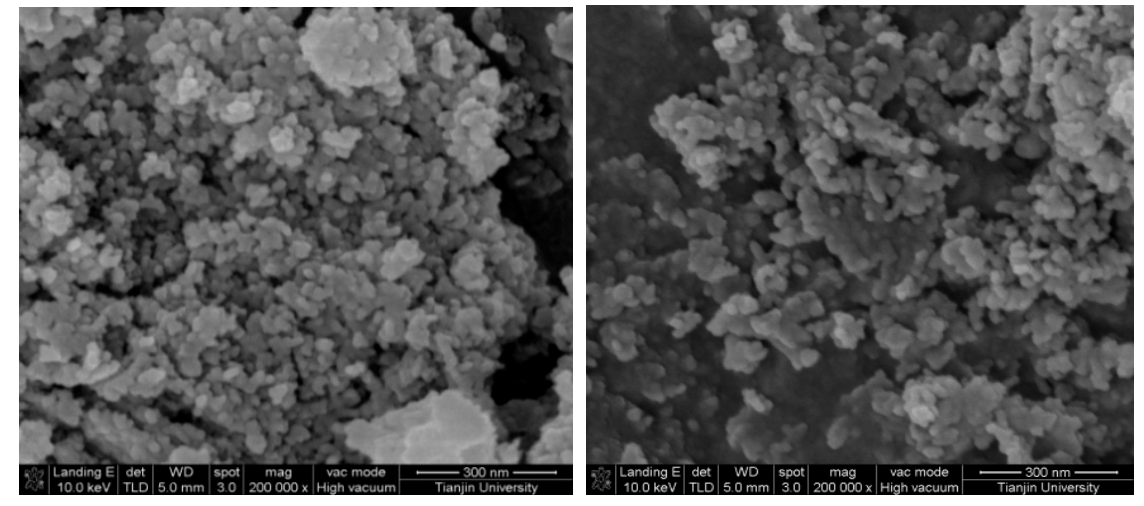

Figure 2. SEM images of catalysts: (a) $0.24 \mathrm{Cu} / \mathrm{MgO}-\mathrm{C}-350$; (b) $0.30 \mathrm{Cu} / \mathrm{MgO}-\mathrm{C}-350$.

The $\mathrm{Cu} / \mathrm{MgO}$ catalysts with different $\mathrm{Cu}$ loadings were alternatively prepared by the impregnation method, and their XRD patterns are exhibited in Figure 3. A $\mathrm{Cu}^{0}$ phase (JCPDS04-0836, $2 \theta=43.3^{\circ}, 50.4^{\circ}$ ) evidently emerges in the samples prepared through the impregnation method [24], which may, compared to the samples prepared by the precipitation method, be due to the presence of more $\mathrm{Cu}\left(\mathrm{NO}_{3}\right)_{2}$ on the catalyst surface and more contact between the $\mathrm{Cu}\left(\mathrm{NO}_{3}\right)_{2}$ and glucose. TEM (Figure 4) images affirm the uniform distribution of $\mathrm{Cu}$ on the surface of the $\mathrm{MgO}$ and the corresponding crystalline grain size of between $20 \sim 30 \mathrm{~nm}$. 


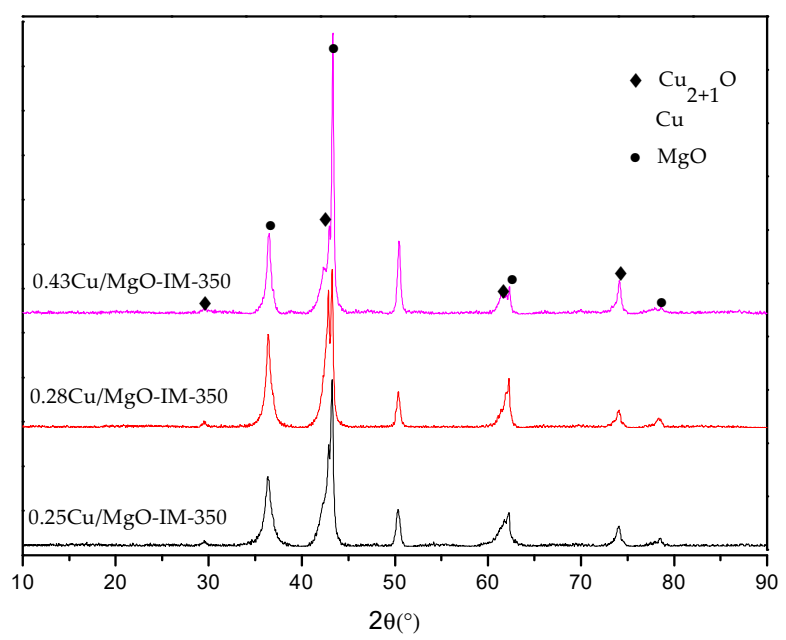

Figure 3. XRD patterns of the $\mathrm{Cu} / \mathrm{MgO}$ catalysts prepared by impregnation method and calcined at $350{ }^{\circ} \mathrm{C}$.
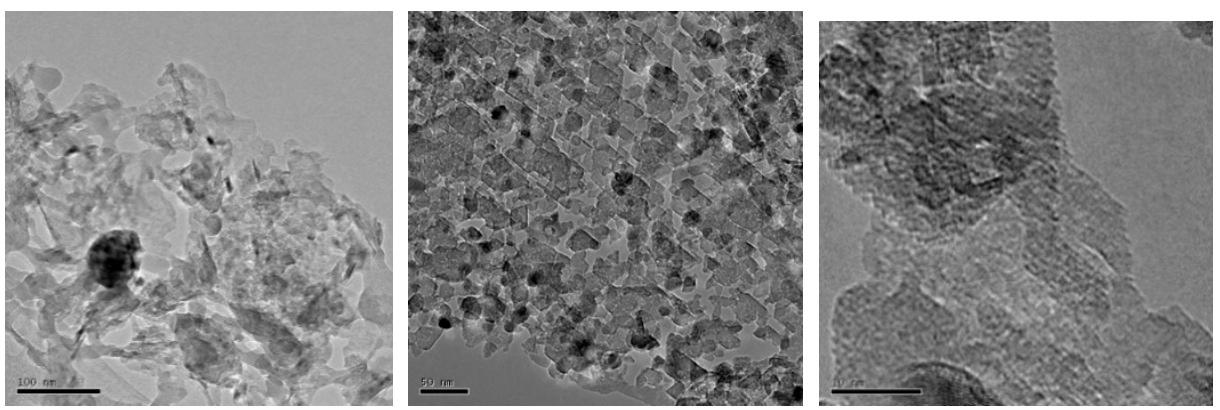

Figure 4. TEM images of the $0.28 \mathrm{Cu} / \mathrm{MgO}-\mathrm{IM}-350$ catalyst prepared by the impregnation method.

Table 3 summarizes the specific surface area, mass ratio of $\mathrm{Cu}$ to $\mathrm{MgO}$ and the crystallite sizes of $\mathrm{Cu}_{2+1} \mathrm{O}$ and $\mathrm{MgO}$ of various $\mathrm{Cu} / \mathrm{MgO}$ catalysts. The composition of the bulk phase of the catalyst was measured by ICP, and the results confirm that the mass ratio of $\mathrm{Cu}$ to $\mathrm{MgO}$ was preserved from the initial loading to post-synthesis. Furthermore, the specific surface area of the as-prepared $\mathrm{Cu} / \mathrm{MgO}$ catalysts gradually decreases and the crystallite size of $\mathrm{Cu}_{2+1} \mathrm{O}$ increases as the $\mathrm{Cu}$-loading increases. The reason for this may be that the $\mathrm{Cu}$ component occupied the pore channel of $\mathrm{MgO}$. It can be seen from Table 1 that after the catalyst was heated for $3 \mathrm{~h}$ at $350{ }^{\circ} \mathrm{C}$, the sizes of the crystalline grain of $\mathrm{Cu}_{2+1} \mathrm{O}$ and $\mathrm{MgO}$ were 20 40 $\mathrm{nm}$ and about $10 \mathrm{~nm}$, respectively. When comparing the different methods of preparing the catalysts, the specific surface area of $\mathrm{Cu} / \mathrm{MgO}$ prepared by precipitation method is greater than that prepared by the impregnation method. The $\mathrm{MgO}$ for the impregnation from $\mathrm{Mg}(\mathrm{OH})_{2}$ was first calcined at $400{ }^{\circ} \mathrm{C}$ for $3 \mathrm{~h}$, which converts the precipitated, amorphous $\mathrm{MgO}$ into a crystalline state and greatly decreases its specific surface, while the crystal size for $\mathrm{Cu}_{2+1} \mathrm{O}$ changed slightly.

Table 3. The composition, crystalline grain size and specific surface area of the catalysts.

\begin{tabular}{ccccc}
\hline \multirow{2}{*}{$\begin{array}{c}\text { Catalysts } \\
\end{array}$} & Specific Surface Area $\left(\mathbf{m}^{2} / \mathbf{g}\right)$ & $\begin{array}{c}\text { Mass Ratio of } \\
\text { Cu to } \mathbf{M g O}^{\mathbf{a}}\end{array}$ & & \multicolumn{2}{c}{$\begin{array}{c}\text { Crystallite Sizes } \\
\text { (nm, XRD) }\end{array}$} \\
\cline { 4 - 5 } & & & $\mathrm{Cu}_{\mathbf{2 + 1}} \mathbf{O}$ & $\mathbf{~ M g O}$ \\
\hline $0.14 \mathrm{Cu} / \mathrm{MgO}-\mathrm{C}-350$ & 49.3 & $0.14: 1$ & 27.8 & 8.8 \\
$0.24 \mathrm{Cu} / \mathrm{MgO}-\mathrm{C}-350$ & 47.4 & $0.24: 1$ & 29.0 & 8.7 \\
$0.30 \mathrm{Cu} / \mathrm{MgO}-\mathrm{C}-350$ & 44.6 & $0.30: 1$ & 34.2 & 11.7 \\
$0.28 \mathrm{Cu} / \mathrm{MgO}-\mathrm{IM}-350^{\mathrm{b}}$ & 29.9 & $0.28: 1$ & 35.2 & 49.2 \\
\hline
\end{tabular}

${ }^{\text {a }}$ Measured by $\mathrm{ICP} ;{ }^{\mathrm{b}} \mathrm{Mg}(\mathrm{OH})_{2}$ was firstly calcined at $400{ }^{\circ} \mathrm{C}$ for $3 \mathrm{~h}$. 
The XPS technique was also employed to characterize the $0.24 \mathrm{Cu} / \mathrm{MgO}-\mathrm{C}-350$ catalyst, and its corresponding result is presented in Figure 5. Since the binding energy of $\mathrm{Cu}^{0}$ and $\mathrm{Cu}^{+}$is very close and cannot be further deconvoluted, the use of $\mathrm{Cu} L M M$ Auger spectrum was instead employed to discriminate between $\mathrm{Cu}^{0}$ and $\mathrm{Cu}^{+}$. There is only one peak $(917.3 \mathrm{eV})$ between $916 \mathrm{eV}$ and $920 \mathrm{eV}$ in Auger electron spectroscopy (not listed), indicating no $\mathrm{Cu}^{0}$ in the sample [24]. The XPS spectrum of $\mathrm{Cu}$ $2 p_{3 / 2}$ was subjected to peak deconvolution to generate two peaks of binding energy at $932.5 \mathrm{eV}$ and $934.8 \mathrm{eV}$, which correspond to $\mathrm{Cu}^{+}$and $\mathrm{Cu}^{2+}$, respectively [38]. Furthermore, the ratio of $\mathrm{Cu}^{2+} / \mathrm{Cu}^{+}$ was 22.8:100 according to the fractal processing of the $\mathrm{Cu} 2 p_{3 / 2}$ peaks. Another method used the correlation between the area of the nearest shake-up peak $(940-945 \mathrm{eV})$ of $\mathrm{Cu}^{2+}$ and its linear equation of area in $\mathrm{Cu} 2 p_{3 / 2}$ [38]. The ratio of $\mathrm{Cu}^{2+} / \mathrm{Cu}^{+}$was consistent with the former on the whole. However, the binding energy of $\mathrm{Cu}^{2+}$ in this sample is higher than that in the literature (the binding energy of $\mathrm{Cu} 2 p_{3 / 2}$ in $\mathrm{CuO}$ is about $933.5 \mathrm{eV}$ ), indicating that there is a stronger interaction between $\mathrm{Cu}^{2+}$ and $\mathrm{MgO}$ or $\mathrm{Cu}_{2} \mathrm{O}$. Furthermore, the $2 p \rightarrow 3 d$ satellite peak at $940 \sim 945 \mathrm{eV}$ further validates the existence of $\mathrm{Cu}^{2+}$ species [24].

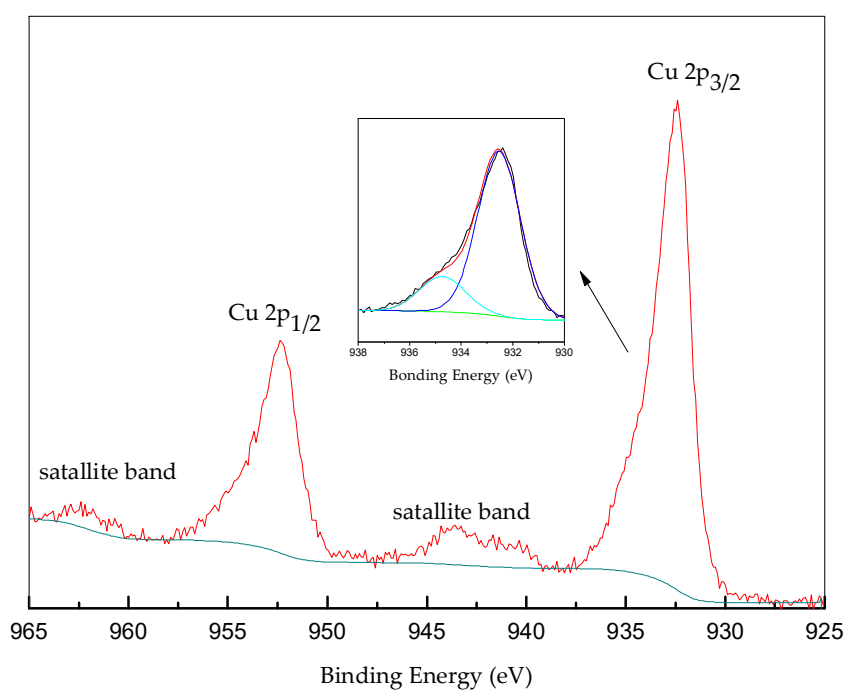

Figure 5. XPS patterns of the $0.24 \mathrm{Cu} / \mathrm{MgO}-\mathrm{C}-350$ catalyst.

Figure 6 contrasts the $\mathrm{H}_{2}$-TPR curves of the $\mathrm{Cu} / \mathrm{MgO}$ catalysts, and the TPR spectra of the investigated catalysts are significantly influenced by the two different methods. It is apparent that the reduction peak area for $\mathrm{Cu} / \mathrm{MgO}$ prepared by the precipitation method is significantly larger than that of the $\mathrm{Cu} / \mathrm{MgO}$ prepared by the impregnation method. From the results of XRD in Figures 1 and 3, the $\mathrm{CuO}$ in $0.28 \mathrm{Cu} / \mathrm{MgO}-\mathrm{IM}-350$ was partially reduced to $\mathrm{Cu}^{0}$ during the preparation process, while most of the $\mathrm{CuO}$ was reduced to $\mathrm{Cu}^{2+1} \mathrm{O}$ in $0.30 \mathrm{Cu} / \mathrm{MgO}-\mathrm{C}-350$, which may be responsible for the difference in the reduction of the peak area. As for the $\mathrm{H}_{2}$ reduction temperature, $0.30 \mathrm{Cu} / \mathrm{MgO}-\mathrm{C}-350$ reduces at a higher temperature of about $220^{\circ} \mathrm{C}$ than that of $0.28 \mathrm{Cu} / \mathrm{MgO}-\mathrm{IM}-350$, which reduce at $186^{\circ} \mathrm{C}$ and $207^{\circ} \mathrm{C}$, respectively, based on the fractal processing of the reduction peak. The temperature is below the reduction temperature of $\mathrm{CuO}$, and the reduction temperature of pure $\mathrm{CuO}$ ranges from $500 \mathrm{~K}$ to $750 \mathrm{~K}$. The single symmetric reduction peak for the former indicated that it was reduced completely in a single-step. It also reveals that $\mathrm{Cu}_{2+1} \mathrm{O}$ species in the catalyst are dispersed uniformly with a single structure. The reason for this may be that most of the $\mathrm{Cu}$ component exists on the surface for $0.28 \mathrm{Cu} / \mathrm{MgO}-\mathrm{IM}-350$, and in the bulk phase for $0.30 \mathrm{Cu} / \mathrm{MgO}-\mathrm{C}-350$, which increases the difficulty of the reduction. 


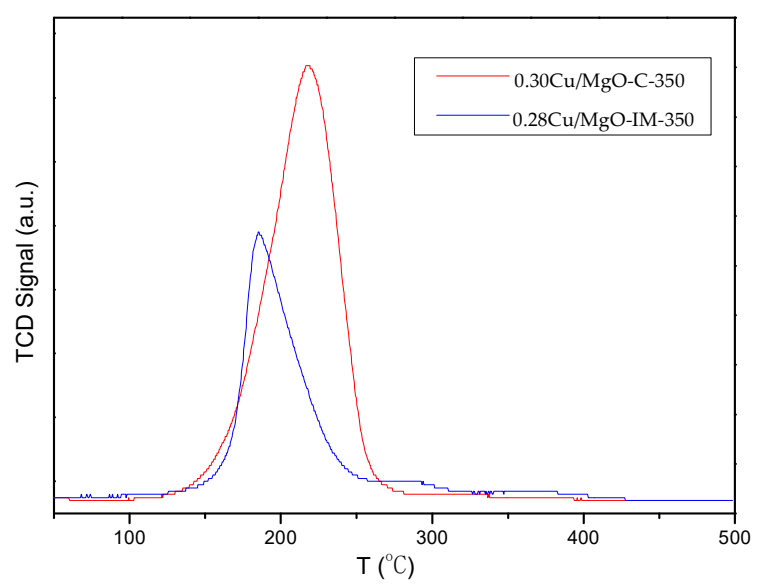

Figure 6. $\mathrm{H}_{2}$ - temperature-programmed reduction (TPR) profiles of $\mathrm{Cu} / \mathrm{MgO}$.

\subsection{Catalytic Performance of $\mathrm{Cu} / \mathrm{MgO}$ in the Dehydrogenation of $\mathrm{CHD}$}

The qualitative analysis of the dehydrogenation was carried out on a GC-MS. It was discovered that the major components in the $\mathrm{CHD}$ dehydrogenation in the presence of $\mathrm{Cu} / \mathrm{MgO}$ were $\mathrm{HCO}$ and HCEO, but the extended dehydrogenation product, pyrocatechol, could not be detected. Other byproducts in the reaction were also detected as expected, such as cyclohexanone, hexanol, etc.

\subsubsection{Effects of Preparation Conditions on the Catalytic Performance of $\mathrm{Cu} / \mathrm{MgO}$}

(1) Effect of $\mathrm{Cu}$ loading

$\mathrm{Cu} / \mathrm{MgO}$ catalysts with different $\mathrm{Cu}$ loadings were prepared, and the influence of $\mathrm{Cu}$ loading on the catalytic performance is listed in Figure 7. In the absence of $\mathrm{Cu}$, the conversion of $\mathrm{CHD}$ was rather low, and the total yield of both HCO and HCEO was also lacking despite the presence of MgO. From this result, it can be surmised that the addition of $\mathrm{Cu}$ to $\mathrm{MgO}$ is crucial to the dehydrogenation of $\mathrm{CHD}$. As the content of $\mathrm{Cu}$ increased, the conversion of $\mathrm{CHD}$ also improved. However, the conversion of $\mathrm{CHD}$ would decline after exceeding a certain $\mathrm{Cu}$ content threshold. More specifically, when the percentage of $\mathrm{Cu}$ is optimized between 20 30\%, the conversion of CHD can exceed $90 \%$ and the yield of the dehydrogenation products, $\mathrm{HCO}$ and HCEO, can surpass $85 \%$. However, when the $\mathrm{Cu}$ content exceeds $30 \%$, both the conversion rate of CHD and the selectivity of $\mathrm{HCO}$ and HCEO would decline, resulting in the increase of other byproducts, such as cyclohexanone and a number of other small molecules.

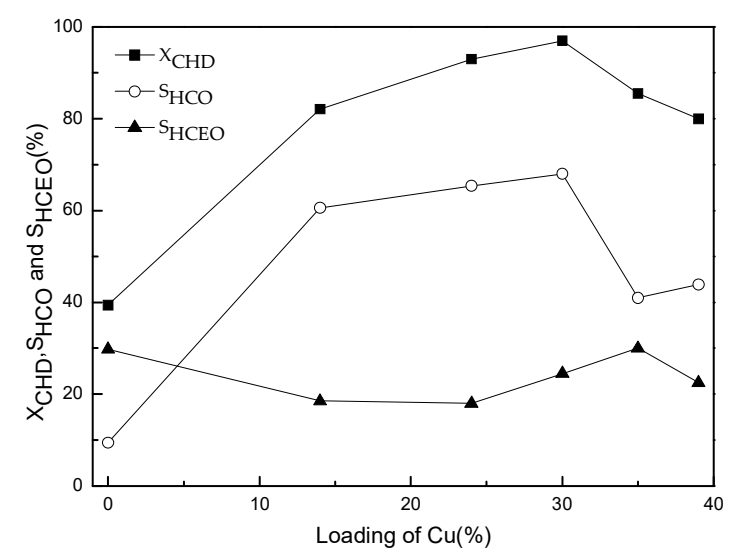

Figure 7. Effect of $\mathrm{Cu}$ loading on the catalytic performance of $\mathrm{Cu} / \mathrm{MgO}^{\mathrm{a}}$. a. Reaction conditions: $\mathrm{N}_{2} 40.0 \mathrm{~mL} / \mathrm{min}$, catalyst $1.0 \mathrm{~g}$, 1,2-cyclohexanediol (CHD) solution $0.05 \mathrm{~mL} / \mathrm{min}, 220{ }^{\circ} \mathrm{C}$. 
(2) Effect of calcination temperature

The effect of the calcination temperature on the catalytic performance was also investigated, and the results are summarized in Figure 8. The calcination temperature has a significant effect on the catalytic performance of $\mathrm{Cu} / \mathrm{MgO}$. More specifically, catalysts calcined at different temperatures have a lesser effect on the conversion of $\mathrm{CHD}$, but will significantly affect the selectivity of the products. When the calcination temperature is below $350{ }^{\circ} \mathrm{C}, \mathrm{Mg}(\mathrm{OH})_{2}$ and a few hydroxyl groups exist within and on the surface of the catalyst, respectively. Due to the surface hydroxyl groups, there exists a strong adsorption capacity between HCO and the catalyst, which was beneficial to the double dehydrogenation of CHD to HCEO. When the calcination temperature is set between $350{ }^{\circ} \mathrm{C}$ and $450{ }^{\circ} \mathrm{C}$, the selectivity of $\mathrm{HCO}$ is apparently greater than that of HCEO. However, the selectivity of the product of the double dehydrogenation easily exceeds that of the first dehydrogenation when the catalyst was calcined at $550{ }^{\circ} \mathrm{C}$. Lastly, the total selectivity of both HCO and HCEO significantly decreased because HCEO would further dehydrate into cyclohexanone and other smaller molecules.

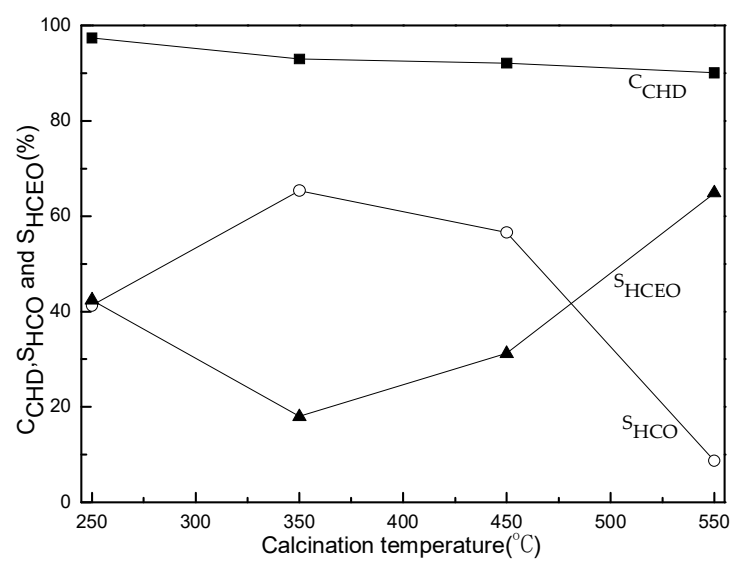

Figure 8. Effect of calcination temperature on the catalytic performance of $\mathrm{Cu} / \mathrm{MgO}^{\mathrm{a}}$. a. Reaction conditions: $\mathrm{N}_{2} 40.0 \mathrm{~mL} / \mathrm{min}$, catalyst $1.0 \mathrm{~g}$, CHD solution $0.05 \mathrm{~mL} / \mathrm{min}, 220{ }^{\circ} \mathrm{C}$.

\subsubsection{Effect of Reaction Conditions on the Dehydrogenation of CHD}

(1). The influence of reaction temperature

The effect of reaction temperature on the dehydrogenation of CHD was studied and the results are exhibited in Figure 9. CHD can undergo a dehydrogenation reaction on the surface of the catalyst at $150{ }^{\circ} \mathrm{C}$, and the selectivity of $\mathrm{HCO}$ and HCEO are essentially equal. However, as the reaction temperature increases, initially, both the conversion of $\mathrm{CHD}$ and selectivity of $\mathrm{HCO}$ will increase while the selectivity of HCEO will decline because HCO desorbs more easily from the catalyst surface at higher temperatures. In addition, when the reaction occurs below $300^{\circ} \mathrm{C}$, the sum of the selectivity of $\mathrm{HCO}$ and HCEO eclipses $85 \%$. However, at a reaction temperature of $300{ }^{\circ} \mathrm{C}$, the $\mathrm{CHD}$ conversion and $\mathrm{HCO}$ selectivity declines sharply. This decline in the catalytic activity can be attributed to the formation of carbon deposits on the catalyst and the decomposition of CHD into smaller molecules. Thus, the optimal reaction temperature was reckoned to be $220^{\circ} \mathrm{C}$. 


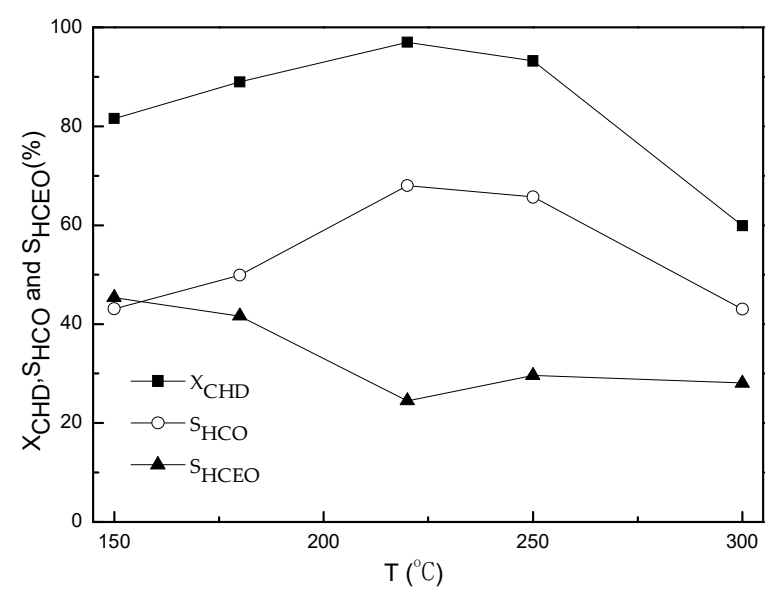

Figure 9. Effect of reaction temperature on the dehydrogenation of $\mathrm{CHD}^{\mathrm{a}}$. a. Reaction conditions: $\mathrm{N}_{2} 40.0 \mathrm{~mL} / \mathrm{min}, 0.30 \mathrm{Cu} / \mathrm{MgO}-\mathrm{C}-3501.0 \mathrm{~g}$, CHD solution $0.05 \mathrm{~mL} / \mathrm{min}$.

(2). Effect of $\mathrm{N}_{2}$ flow rate

In fixed-bed reactors, inert gases are incorporated as carrier gases to dilute the active material of interest. The effect of the $\mathrm{N}_{2}$ flow rate was studied and the results are reported in Figure 10. As seen, the CHD conversion and HCO selectivity initially increased, then decreased during the gradual increase of $\mathrm{N}_{2}$ flow. This can be explained by the poor material dispersion at lower $\mathrm{N}_{2}$ flow rates, which led to the low conversion of $\mathrm{CHD}$ and the slow desorption rate of HCO from the catalyst surface. As a result, there is a comparatively higher selectivity of HCEO. When the $\mathrm{N}_{2}$ flow rate increased to $40 \mathrm{~mL} / \mathrm{min}$, the CHD conversion and HCO selectivity reached their maxima at $97.0 \%$ and $68.0 \%$, respectively, while the selectivity of $\mathrm{HCEO}$ decreased to $24.5 \%$. From this perspective, increasing the $\mathrm{N}_{2}$ flow rate caused the CHD conversion, $\mathrm{HCO}$ selectivity and HCEO selectivity to decrease because the residence time was apparently too short for this reaction.

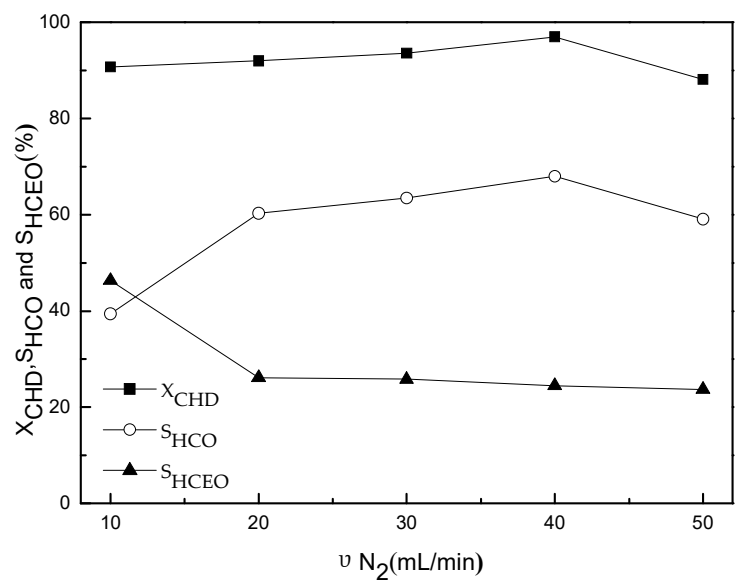

Figure 10. Effect of the $\mathrm{N}_{2}$ flow rate on the dehydrogenation of 1,2-cyclohexanediol ${ }^{\mathrm{a}}$. a. Reaction conditions: $0.30 \mathrm{Cu} / \mathrm{MgO}-\mathrm{C}-3501.0 \mathrm{~g}$, CHD solution $0.05 \mathrm{~mL} / \mathrm{min}, 220^{\circ} \mathrm{C}$.

\section{Conclusions}

(1) The thermodynamic analysis of CHD dehydrogenation was conducted by DFT. HCO, HCEO and pyrocatechol were produced from the dehydrogenation reaction. The three steps of CHD dehydrogenation were all endothermic, in which the heat absorption of the second step was the largest.

(2) $\mathrm{Cu} / \mathrm{MgO}$ catalysts were prepared with glucose as the reductant to catalyze the oxygen-free dehydrogenation of $\mathrm{CHD}$. The $\mathrm{Cu}_{2+1} \mathrm{O}$ phase is the main catalytic site, and the strong interaction 
between $\mathrm{Cu}_{2+1} \mathrm{O}$ and $\mathrm{MgO}$ is also beneficial to the reaction. $\mathrm{Cu} / \mathrm{MgO}$ has a high catalytic selectivity towards $\mathrm{HCO}$ and $\mathrm{HCEO}$, but no pyrocatechol was formed over $\mathrm{Cu}_{2+1} \mathrm{O} / \mathrm{MgO}$ catalysts. The highest yields of $\mathrm{HCO}$ and HCEO were $68.0 \%$ and $24.5 \%$, respectively, while the highest conversion rate of CHD was $97.0 \%$.

This study provides both high value-added chemicals and environmentally-friendly hydrogen energy. The above routes can also be used in the dehydrogenation of renewable polyhydroxy biomass.

Author Contributions: Conceptualization and methodology, H.O.; software and data curation, Q.S.; investigation, Y.C.; writing_-original draft preparation, H.O.; writing-review and editing, Q.S.; supervision and funding acquisition, Y.J.

Funding: This research was funded by the National Natural Science Foundation of China, grant number 21236001.

Conflicts of Interest: The authors declare no conflicts of interest.

\section{References}

1. Zhou, G.; Dong, Y.; Jiang, L.; He, D.; Yang, Y.; Zhou, X. Effect of support composition on the structural and catalytic properties of $\mathrm{Ru} / \mathrm{AlOOH}-\mathrm{SiO}_{2}$ catalysts for benzene selective hydrogenation. Catal. Sci. Technol. 2018, 8, 1435-1446. [CrossRef]

2. Spod, H.; Lucas, M.; Claus, P. Selective hydrogenation of benzene to cyclohexene over $2 \mathrm{Ru} / \mathrm{La}_{2} \mathrm{O}_{3}-\mathrm{ZnO}$ catalyst without additional modifiers. ChemCatChem 2016, 8, 2659-2666. [CrossRef]

3. Liu, J.; Xu, S.; Bing, W.; Wang, F.; Li, C.; Wei, M.; Evans, D.G.; Duan, X. Cu-decorated Ru catalysts supported on layered double hydroxides for selective benzene hydrogenation to cyclohexene. ChemCatChem 2015, 7, 846-855. [CrossRef]

4. Yan, X.; Zhang, Q.; Zhu, M.; Wang, Z. Selective hydrogenation of benzene to cyclohexene over Ru-Zn/ZrO 2 catalysts prepared by a two-step impregnation method. J. Mol. Catal. A Chem. 2016, 413, 85-93. [CrossRef]

5. Alimardanov, K.M.; Sadygov, O.A.; Garibov, N.I.; Abbasov, M.F.; Abdullaeva, M.Y.; Dzhafarova, N.A. Liquid-phase catalytic oxidation of $\mathrm{C}_{6}-\mathrm{C}_{7}$ cycloolefins into carboxylic acids in a pseudohomogeneous system. Russ. J. Appl. Chem. 2011, 84, 236-242. [CrossRef]

6. Saha, D.; Hazra, D.K.; Maity, T.; Koner, S. Heterometallic metal-organic frameworks that catalyze two different reactions sequentially. Inorg. Chem. 2016, 55, 5729-5731. [CrossRef] [PubMed]

7. Damm, M.; Gutmann, B.; Kappe, C.O. Continuous-flow synthesis of adipic acid from cyclohexene using hydrogen peroxide in high-temperature explosive regimes. ChemSusChem 2013, 6, 978-982. [CrossRef]

8. Chen, B.H.; Liu, W.; Li, A.; Liu, Y.J.; Chao, Z.S. A simple and convenient approach for preparing core-shell-like silica@nickel species nanoparticles: Highly efficient and stable catalyst for the dehydrogenation of 1,2-cyclohexanediol to catechol. Dalton T. 2015, 44, 1023-1038. [CrossRef]

9. Paushkin, Y.M.; Nizova, S.A.; Stytsenko, V.D.; Belov, P.S.; Rozovskii, A.Y.; D’Yakonov, A.Y. Preparation of pyrocatechol and its alkyl and aryl derivatives. Dokl. Chem. 1983, 271, 217-219.

10. Zhou, Z.Z.; Liu, M.; Lv, L.; Li, C.J. Silver(I)-catalyzed widely applicable aerobic 1,2-diol oxidative cleavage. Angew. Chem. Int. Edit. 2018, 57, 2616-2620. [CrossRef]

11. Ghosh, S.; Acharyya, S.S.; Adak, S.; Konathala, L.N.S.; Sasaki, T.; Bal, R. Selective oxidation of cyclohexene to adipic acid over silver supported tungsten oxide nanostructured catalysts. Green Chem. 2014, 16, 2826-2834. [CrossRef]

12. Zhang, C.; Qi, J.; Xing, J.; Tang, S.F.; Song, L.; Sun, Y.; Zhang, C.; Xin, H.; Li, X. An investigation on the aqueous-phase hydrodeoxygenation of various methoxy-substituted lignin monomers on Pd/C and HZSM-5 catalysts. RSC. Adv. 2016, 6, 104398-104406. [CrossRef]

13. Cho, C.S.; Oh, S.G. A new ruthenium-catalyzed approach for quinoxalines from ortho-phenylenediamines and vicinal-diols. Tetrahedron Lett. 2006, 47, 5633-5636. [CrossRef]

14. Lee, H.; Yi, C.S. Catalytic synthesis of substituted indoles and quinolines from the dehydrative C-H coupling of arylamines with 1,2- and 1,3-Diols. Organometallics 2016, 35, 1973-1977. [CrossRef] [PubMed]

15. Xiong, B.; Zhang, S.D.; Chen, L.; Li, B.; Jiang, H.F.; Zhang, M. An annulative transfer hydrogenation strategy enables straightforward access to tetrahydro fused-pyrazine derivatives. Chem. Commun. 2016, 52, 10636-10639. [CrossRef] [PubMed] 
16. Bierenstiel, M.; D'Hondt, P.J.; Schlaf, M. Investigations into the selective oxidation of vicinal diols to $\alpha$-hydroxy ketones with the $\mathrm{NaBrO}_{3} / \mathrm{NaHSO}_{3}$ reagent: $\mathrm{pH}$ dependence, stoichiometry, substrates and origin of selectivity. Tetrahedron 2005, 61, 4911-4917. [CrossRef]

17. William, J.M.; Kuriyama, M.; Onomura, O. An efficient method for selective oxidation of 1,2-Diols in water catalyzed by $\mathrm{Me}_{2} \mathrm{SnCl}_{2}$. RSC. Adv. 2013, 3, 19247-19250. [CrossRef]

18. Obara, N.; Hirasawa, S.; Tamura, M.; Nakagawa, Y.; Tomishige, K. Oxidative cleavage of vicinal diols with the combination of platinum and vanadium catalysts and molecular oxygen. ChemCatChem 2016, 8 , 1732-1738. [CrossRef]

19. Hsiao, M.C.; Liu, S.T. Polymer supported vanadium complexes as catalysts for the oxidation of alkenes in water. Catal. Lett. 2010, 139, 61-66. [CrossRef]

20. Verma, S.; Jain, S.L.; Sain, B. Poly(ethylene glycol) embedded potassium tribromide $\left(\mathrm{PEG} \mathrm{KBr}_{3}\right)$ as a recyclable catalyst for oxidation of alcohols. Ind. Eng. Chem. Res. 2011, 50, 5862-5865. [CrossRef]

21. Khenkin, A.M.; Neumann, R. Aerobic oxidation of vicinal diols catalyzed by an anderson-type polyoxometalate, $\left[\mathrm{IMo}_{6} \mathrm{O}_{24}\right]^{5-}$. Adv. Synth. Catal. 2002, 344, 1017-1021. [CrossRef]

22. Sato, H.; Tamura, M.; Nakagawa, Y.; Tomishige, K. Synthesis of alpha-hydroxy ketones from vicinal diols by selective dehydrogenation over $\mathrm{Ir}-\mathrm{ReO}_{X} / \mathrm{SiO}_{2}$ catalyst. Chem. Lett. 2014, 43, 334-336. [CrossRef]

23. Zhou, G.D.; Guo, X.H.; Lu, X.J.; Li, Y.N.; Cheng, T.X.; Li, W.X.; Zhen, K.J. MgO-Supported $\mathrm{Cu}_{2} \mathrm{PMo}_{11} \mathrm{VO}_{40}$ Catalyst for Oxidative Dehydrogenation of n-Hexanol to n-Hexanal. Chin. J. Catal. 2005, 26, 389-392.

24. Ji, D.; Zhu, W.; Wang, Z.; Wang, G. Dehydrogenation of cyclohexanol on Cu-ZnO/SiO 2 catalysts: The role of copper species. Catal. Commun. 2007, 8, 1891-1895. [CrossRef]

25. Fridman, V.Z.; Davydov, A.A.; Titievsky, K. Dehydrogenation of cyclohexanol on copper-containing catalysts: II. The pathways of the cyclohexanol dehydrogenation reaction to cyclohexanone on copper-active sites in oxidation state $\mathrm{Cu}^{0}$ and $\mathrm{Cu}^{+}$. J. Catal. 2004, 222, 545-557. [CrossRef]

26. Fridman, V.Z.; Davydov, A.A. Dehydrogenation of cyclohexanol on copper-containing catalysts: I. The influence of the oxidation state of copper on the activity of copper sites. J. Catal. 2000, 195, 20-30. [CrossRef]

27. Luna, A.; Alcamí, M.; Mó, O.; Máñez, M. $\mathrm{Cu}^{+}$reactivity trends in $\mathrm{sp}, \mathrm{sp}^{2}$, and $\mathrm{sp}^{3}$ nitrogen, phosphorus, and arsenic containing bases. Int. J. Mass. Spectrom 2000, 201, 215-231. [CrossRef]

28. Trost, B.M.; Schroeder, G.M. Cyclic 1,2-diketones as building blocks for asymmetric synthesis of cycloalkenones. J. Am. Chem. Soc. 2000, 122, 3785-3786. [CrossRef]

29. Svennebring, A.; Nilsson, P.; Larhed, M. Microwave-accelerated spiro-cyclizations of o-halobenzyl cyclohexenyl ethers by palladium (0) catalysis. J. Org. Chem. 2007, 72, 5851-5854. [CrossRef]

30. Jeena, V.; Robinson, R.S. Green oxidations: Titanium dioxide induced tandem oxidation coupling reactions. Beilstein. J. Org. Chem. 2009, 5, 24. [CrossRef]

31. Araki, Y.; Miyawaki, A.; Miyashita, T.; Mizutani, M.; Hirai, N.; Todoroki, Y. A new non-azole inhibitor of ABA 8 -hydroxylase: Effect of the hydroxyl group substituted for geminal methyl groups in the six-membered ring. Bioorg. Med. Chem. Lett. 2006, 16, 3302-3305. [CrossRef]

32. Cleghorn, L.A.T.; Cooper, I.R.; Fishwick, C.W.G.; Grigg, R.; MacLachlan, W.S.; Rasparini, M.; Sridharan, V. Three-component bimetallic ( $\mathrm{Pd} / \mathrm{In}$ ) mediated cascade allylation of $\mathrm{C}=\mathrm{X}$ functionality: Part 1 . Scope and class 1 examples with aldehydes and ketones. J. Organomet. Chem. 2003, 687, 483-493. [CrossRef]

33. Frisch, M.J.; Trucks, G.W.; Schlegel, H.B.; Scuseria, G.E.; Robb, M.A.; Cheeseman, J.R.; Scalmani, G.; Barone, V.; Petersson, G.A.; Nakatsuji, H.; et al. Gaussian 09, Revision C. 01; Gaussian, Inc.: Wallingford, CT, USA, 2016; Available online: http:/ / gaussian.com/g09citation/ (accessed on 9 February 2019).

34. Tomasi, J.; Mennucci, B.; Cances, E. The IEF version of the PCM solvation method: an overview of a new method addressed to study molecular solutes at the QM ab initio level. J. Mol. Struct. 1999, 464, 211-226. [CrossRef]

35. Xu, G.Y.; Guo, J.H.; Qu, Y.C.; Zhang, Y.; Fu, Y.; Guo, Q.X. Selective hydrodeoxygenation of lignin-derived phenols to alkyl cyclohexanols over a Ru-solid base bifunctional catalyst. Green Chem. 2016, 18, 5510-5517. [CrossRef]

36. Song, W.; Liu, Y.; Baráth, E.; Zhao, C.; Lercher, J.A. Synergistic effects of Ni and acid sites for hydrogenation and C-O bond cleavage of substituted phenols. Green Chem. 2015, 17, 1204-1218. [CrossRef] 
37. Liu, T.; Ma, P.C.; Yu, J.K.; Li, L.; Liu, X.; Ma, B. Preparation of MgO by Thermal Decomposition of $\mathrm{Mg}(\mathrm{OH})_{2}$. J. Chin. Ceram. Soc. 2010, 38, 1337-1340.

38. Meda, L.; Cerofolini, G.F. A decomposition procedure for the determination of copper oxidation states in Cu-zeolites by XPS. Surf. Interface Anal. 2004, 36, 756-759. [CrossRef] 